\title{
Productivity assessment of timber harvesting techniques for supporting sustainable forest management of secondary Atlantic Forest in southern Brazil
}

\author{
P.C. Britto, D. Jaeger, S. Hoffmann, R.C.G. Robert, A.C. Fantini, A.C. Vibrans
}

Britto P.C., Jaeger D., Hoffmann S., Robert R.C.G., Fantini A.C., Vibrans

A.C., 2017. Productivity assessment of timber harvesting techniques for supporting sustainable forest management of secondary Atlantic Forest in southern Brazil. Ann. For. Res. 60(2): 203-215.

Abstract. The Atlantic Forest in southern Brazil has been subject to overexploitation in the past prompting the formulation of a rigorous conservation orientated policy by the government including a strict ban of timber harvesting. In the region, the forestland is mostly owned by farmers. The economic value of the forest is rather limited for those farmers, because of the prohibition of commercial timber harvesting as a source of income. Sustainable forest management systems can offer great potential as new income opportunities for land holders, and further actively support the process of ecosystem rehabilitation and protection of these ecosystems. Yet, successful implementation of such sustainable management systems requires feasible and adapted timber harvesting systems. In order to develop such harvesting systems, a regional comparative case study was conducted at a typical smallholder forestry venture with the objective to analyze and evaluate harvesting methods supporting sustainable management of the Atlantic Forest. This study assessed production rates and associated costs of a common conventional timber harvesting method (CM) and a proposed alternative method (AM). CM was performed by a selected, typical forest landowner who had only basic training in chainsaw operations, but 20 years of experience at the wood yard of his small sawmill. In contrast, AM employed a professional chainsaw operator from the Amazon forest, trained and experienced in reduced impact logging techniques using state of the art equipment, supplemented by a snatch block and a skidding cone for improved extraction. Time study based models identified tree volume, winching distance and skidding distance to landing as the most significant independent variables affecting productivity. Total net productivity ranged from $4.9 \mathrm{~m}^{3} \mathrm{PMH}_{0}^{-1}$ for $\mathrm{CM}$ to $3.1 \mathrm{~m}^{3} \mathrm{PMH}_{0}^{-1}$ for AM. Corresponding gross-productivity ranged from $3.0 \mathrm{~m}^{3} \mathrm{SMH}^{-1}$ to $1.9 \mathrm{~m}^{3} \mathrm{SMH}^{-1}$ with an overall mean utilization rate of $60.8 \%$ and $60.9 \%$, respectively for $\mathrm{CM}$ and $\mathrm{AM}$. Associated harvesting costs ranged from 12.05 $€ \mathrm{~m}^{-3}$ to $20.94 € \mathrm{~m}^{-3}$ with an estimated annual production of $4000 \mathrm{~m}^{3}$ and $2700 \mathrm{~m}^{3}$, respectively. Although AM showed overall lower productivity and higher costs, it enabled important improvements in terms of occupational 
health and safety. In conclusion, a suitable harvesting system should integrate local experiences of $\mathrm{CM}$ and proposed technical improvements of AM. Keywords forest harvesting, time study, cable winch, secondary forest management

Authors. Pedro Caldas Britto (pedro.britto@foresteng.uni-freiburg.de) - Faculty of Environment and Natural Resources, University of Freiburg, Germany; Dirk Jaeger, Stephan Hoffmann - Department of Forest Work Science and Engineering, University of Göttingen, Germany; Renato Cesar Gonçalves Robert Forestry \& Wood Science Center, Federal University of Paraná (UFPR), Brazil; Alfredo Celso Fantini - Laboratory of Ecology and Management of Forest Ecosystems, Federal University of Santa Catarina (UFSC), Brazil; Alexander C. Vibrans - Department of Forest Engineering. University of Blumenau, Brazil. Manuscript received August 28, 2017; revised November 3, 2017; accepted November 10, 2017; online first November 30, 2017.

\section{Introduction}

The Atlantic Forest is located along the Brazilian coast and up to the 1900s it was one of the largest rainforests in the Americas, originally covering approximately 150 million hectares (Metzger 2009). Due to its location, the Atlantic Forest was an easy target for intensive exploitation and conversion to other land-uses. In the past century, the forest land base shrunk by the expansion of agriculture and urbanization to about $12 \%$ of its original size (Ribeiro et al. 2009). Most of the remaining fragments of the Atlantic Forest are small and isolated patches of second growth vegetation in early to medium stages of typical succession fallow areas (Metzger 2009). Only a few large fragments were preserved in locations where steep terrain made exploitation particularly difficult (Silva et al. 2007, Ribeiro et al. 2009).

Conservation and management of the forest ecosystem are currently largely conflicting goals in the Brazilian Atlantic Forest region. Irrespective of size, all fragments of the Atlantic Forest are protected and timber harvesting is banned (Fantini \& Siminski 2016). Moreover, environmental regulations for protecting remaining forests proved to be ineffective as landowners were not compensated and law enforcement was insufficient (Alarcon et al. 2011). Constrained by environmental regulations, implemented to protect remaining for- ests, farmers did no longer benefit from forest management as a source of income. This situation is still ongoing and partly induced, at least, by the lack of knowledge on potentially suitable forest management practices for sustainable resource utilization including various stakeholder groups, landowners and regulatory agencies and authorities.

Alarcon et al. (2011) pointed out the necessity for a policy to promote sustainable forest management of native species from secondary forests. Nonetheless, studies to support effective policy-making for allowing and regulating potential utilization of native trees from the Atlantic Forest and associated harvesting operations and timber production logistics are scarce. New approaches for safeguarding the Atlantic Forest are therefore needed and should focus on sustainable management with regulated timber utilization, combined with governmental incentives providing income opportunities for local farmers and, as such, securing and protecting the Atlantic Forest ecosystem (Alarcon et al. 2015).

Fantini \& Siminski (2016) estimated the mature harvestable timber volume of the secondary Atlantic Forest at 36 million cubic meter in Santa Catarina state, only. The authors also pointed out that wood from secondary forests has a good market and may reach revenues of $260 € \mathrm{~m}^{-3}$ to $340 € \mathrm{~m}^{-3}$ while wood from regional pine and eucalyptus plantations may reach 
comparatively lower revenues of $130 € \mathrm{~m}^{-3}$ to $210 € \mathrm{~m}^{-3}$. To join this market and for the success of sustainable forest management an appropriate harvesting system is essential which needs to be economically viable, environmentally sound and addresses specifics of the local forest.

A suitable harvesting system has to support the achievement of the management goal and therefore needs to be adapted to terrain conditions, stand characteristics, and tree size (Akay et al. 2006). Although urgently needed, studies about timber harvesting systems applied in the Atlantic Forest region are scarce, because of forest regulations that currently ban commercial timber harvesting (Alarcon et al. 2011). This study aims to contribute to fill this gap. Through a case study, we investigated productivity and costs of a conventional timber harvesting method and compared it with an improved and potentially suitable harvesting and extraction method. The specific objectives of the study were: 1) to develop numerical models for work time demand; 2) to estimate production rates and costs; 3) to conclude on future opportunities improving harvesting systems for sustainable management of the Atlantic Forest and its relevance for small landowners.

\section{Materials and methods}

\section{Research area}

The research site was located in the municipality of Guaramirin in Santa Catarina State, southern Brazil $\left(26^{\circ} 32^{\prime} 10^{\prime \prime} \mathrm{S}\right.$ and 49 $02^{\prime} 38^{\prime \prime}$ $\mathrm{W})$, close to the coastline (Figure 1). The climate in Guaramirim is sub-tropical, with temperature heights of about $31^{\circ} \mathrm{C}$ and intense monthly precipitation (between $220 \mathrm{~mm}$ and $230 \mathrm{~mm}$ ) occurring in January while lowest mean temperatures (about $10^{\circ} \mathrm{C}$ ) and precipitation (about $80 \mathrm{~mm}$ and $120 \mathrm{~mm}$ ) are recorded between June and July (Pandolfo et al. 2002). The study was conducted between October 2016 and January 2017, with a mean tempera-

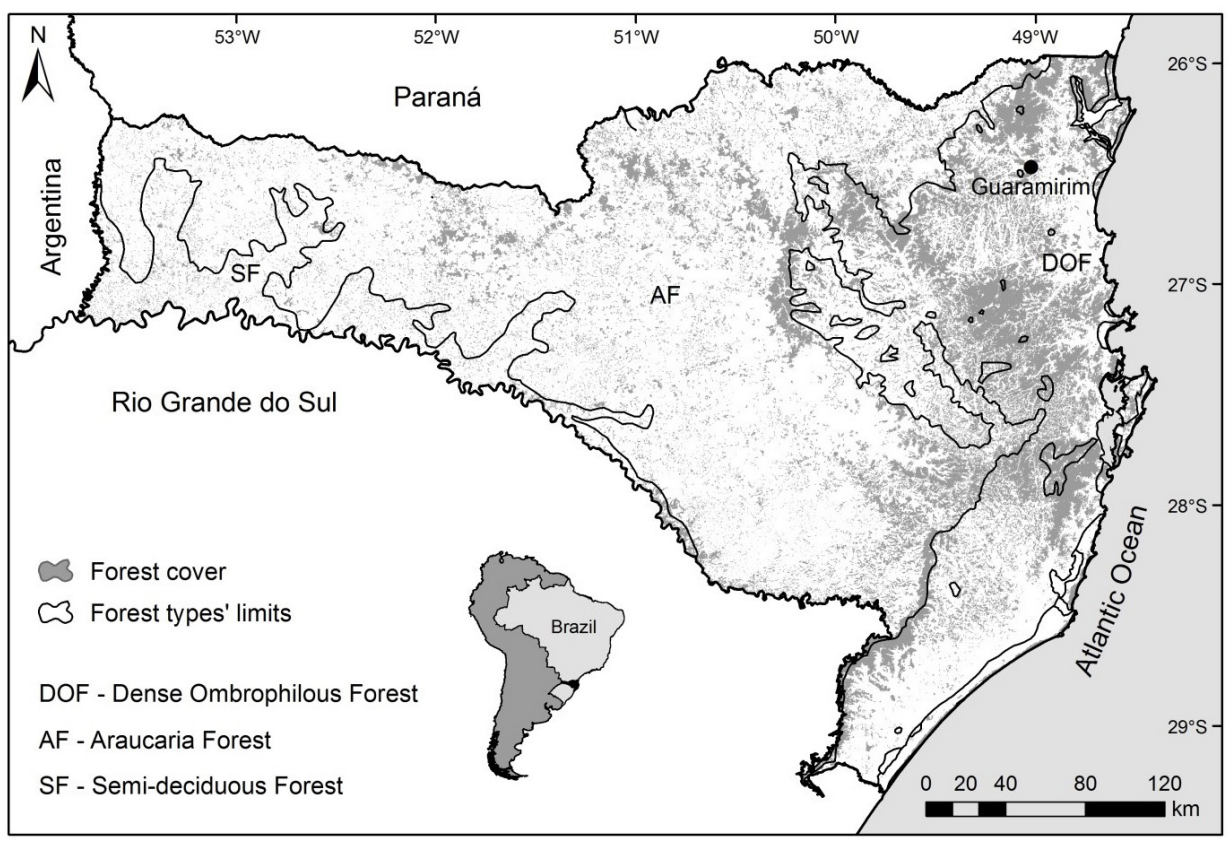

Figure 1 Map of the research area 
ture of about $24{ }^{\circ} \mathrm{C}$ and mean precipitation of about $150 \mathrm{~mm}$ per month.

The total size of the case study area was 42 ha. The forest cover consisted of 35 year old second growth forest, regenerating after swidden agricultural farming plots were abandoned. The landowner possesses and ran a small sawmill, where the timber produced during this study was further processed.

This case study site was a unique area in the Atlantic Forest, since it was exempted of the harvesting ban by the environmental agency of Santa Catarina state (FATMA). Thus, it served as a pilot site to test and evaluate alternative forest management regimes for sustainable utilization concepts. This pilot site showed typical stocking and operating conditions for secondary forests of Dense Ombrophilous Forest (DOF) in the Atlantic Forest (Klein 1978, IBGE 2012).

Two stands, accounting 1.4 ha in total, were selected for this study. Every stand was subdivided into two plots for the application and comparison of two harvesting and extraction methods. A pre-harvest inventory of all trees above $5 \mathrm{~cm}$ of diameter at breast height (DBH) was conducted, recording tree species, DBH and tree height (table 1). Measured trees were permanently marked with a steel tag allowing for recurring assessments of plots in the future. A thinning plan was developed and implemented, considering species composition, ecological groups, tree age, and tree growth. Trees selected for harvesting were separated into two groups: on one hand trees of commercial value, generating revenue and with an economic interest of the landowner to conduct the operation, and on the other hand small dimensional trees of low quality which were harvested to improve the growing conditions of neighbouring trees and to enhance the quality of the remaining stand.

Following this strategy, a total of 145 trees were selected and harvested. Out of these, 106 valuable trees of commercial interest were extracted to a final landing for further transportation to the mill. The remaining 39 trees (improvement cuts of no commercial value) were cut and left behind in the stands. The analysis of inventory data from the two stands showed no significant difference in structure (tree DBH and tree height) when applying nonparametric Whitney U Test $(p<0.05)$. Consequently, the stands were rated as suitable for the study since all occurring differences could be associated to the two different harvesting methods applied.

\section{Harvesting methods}

In this study, two different harvesting methods were assessed and evaluated: The "Conventional Method" (CM), which was formerly widely used by landowners in the region for timber harvesting operations in the Atlantic Forest; and the "Alternative Method" (AM), with a trained operator combined with improvements in technology application as an integral part to implement sustainable forest management.

CM tree felling and delimbing was carried out in the stand using a chainsaw (model Stihl 251). The chainsaw operator did not receive

Table 1 Main characteristics of the harvested stands

\begin{tabular}{lcc}
\hline Characteristics of the stands & Stand A & Stand B \\
\hline Area (ha) & 0.72 & 0.72 \\
Density $\left(\right.$ trees ha $\left.{ }^{-1}\right)$ & 953 & 835 \\
Mean DBH $(\mathrm{cm})$ & $12.1^{\mathrm{a}}$ & $11.6^{\mathrm{a}}$ \\
Standard deviation DBH $(\mathrm{cm})$ & 9.2 & 6.9 \\
Basal area $\left(\mathrm{m}^{2} \mathrm{ha}^{-1}\right)$ & 40.8 & 29.1 \\
Number of felled trees & 73 & 72 \\
Removed basal area $\left(\mathrm{m}^{2} \mathrm{ha}^{-1}\right)$ & 7.8 & 6.3 \\
Terrain slope $(\%)$ & $\approx 50($ steep) & $\approx 15$ (moderate to steep) \\
\hline
\end{tabular}


any specific training to carry out the work, but he had more than 20 years of experience at the wood yard of his small sawmill. Stem length logs were extracted by a Valmet tractor model $85(2 \times 4,63 \mathrm{~kW})$ operated by the chainsaw operator himself. The tractor was equipped with a forestry winch TMO model Caçador 33T and a steel cable with $15 \mathrm{~mm}$ of diameter and $100 \mathrm{~m}$ length (Figure 2a). From the felling site the logs were winched to the tractor road by using the tractor winch. In order to minimize the impact on residual trees, the tractor was positioned outside the stand on the tractor road during the winching and aligned in different positions, enabling shortest suitable winching corridors. After the logs were winched to the tractor road, loads of two to five logs were skidded to the landing.

AM felling was also conducted with a chainsaw (model Stihl 661), but executed by a welltrained and experienced professional chainsaw operator from the Amazon tropical high forest region. Although the operator was skilled in directional and reduced impact felling techniques, he had no experience working in secondary Atlantic Forest. Timber extraction was performed with a Valmet tractor model 128 $(4 \times 4,94 \mathrm{~kW})$ and a TAJFUN winch model EGV 85 AHK (Figure 2b) with a steel cable of $11 \mathrm{~mm}$ diameter and $80 \mathrm{~m}$ length, representing state of the art of PTO driven forestry winches. In contrast to the TMO winch, the TAJFUN winch was equipped with a fairlead, a winch blade and safety features such as cable guards. The tractor was operated by a professional tractor operator experienced in forest plantations, but with no experience in secondary Atlantic Forest or natural forest. Within both systems, an additional helper supported the operators to pull out the cable from the tractor winch to the log location inside the stand. A Portable Winch ${ }^{\circledR}$ skidding cone (Figure $2 \mathrm{c}$ ) and a TAJ-
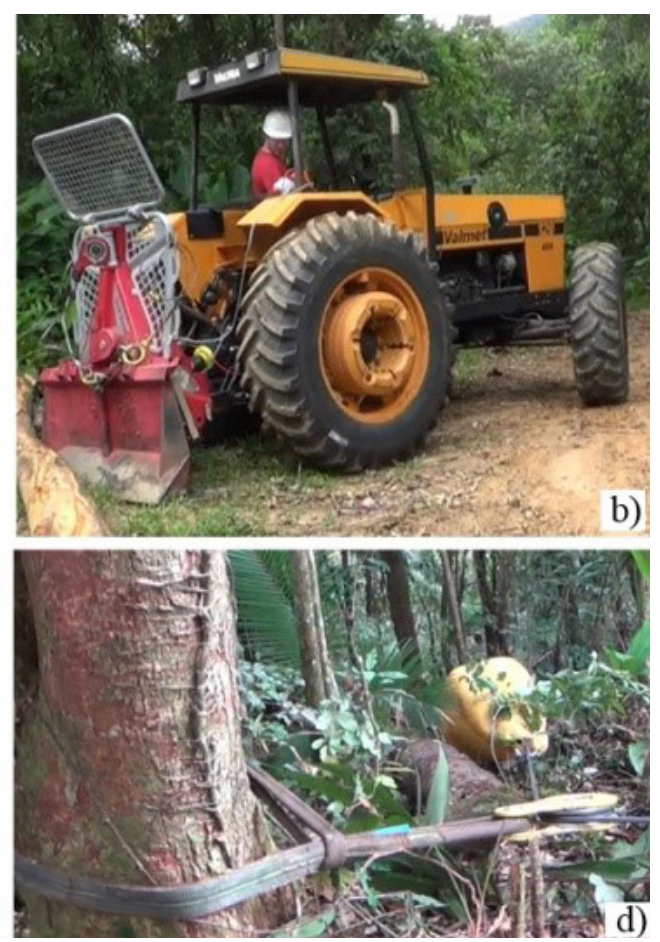

Figure 2 a) Tractor winch in the conventional method; b) Tractor winch in the alternative method; c) Skidding cone; d) Snatch block. 
FUN snatch block (Figure 2d) were introduced to the system in order to complement the alternative method. The skidding cone was made of high-performance plastic and designed for logs up to $50 \mathrm{~cm}$ diameter. The cone was used for reducing ground friction and for preventing logs from colliding with roots, stumps, rocks, remaining trees and other obstacles (Acar 2016). The snatch block was used as a pulley allowing for steering the log extraction direction in the stand and as such deviating logs from rocks, remaining crop trees and other obstacles. Picchio et al. (2012) reported that the use of a snatch block significantly reduced the damage to the residual stand and to the regeneration in a small scale forest operation.

\section{Data collection and data analysis}

Manual time studies applying the continuous time method (Magagnotti \& Spinelli 2012) were used in order to analyze the harvesting methods. A hand chronometer was used for timing in resolution of $1 / 100$ minutes. Work phases were defined by individually timed cycle elements (Björheden \& Thompson 2000). For estimating production rate (in $\mathrm{m}^{3}$ per productive machine hour - hereafter $\mathrm{PMH}_{0}^{-1}$ ) only productive net time without any delays was considered (Koutsianitis \& Tsioras 2016). The utilization rate was estimated as the ratio between productive work time $\left(\mathrm{PMH}_{0}\right)$ and scheduled machine hours (SMH) assigned to the operation.

After the operation, the extraction distances were measured using a stock map which was drawn during the inventory process already and included all tree positions. Furthermore, the volume over bark of all logs at landing was calculated by measuring their length and their diameters at base, half and full lengths.

Measured time was categorized into (1) productive work time and (2) non-productive work time. The productive work time was described with its work elements in table 2. The non-productive work time consisted of: (2a) service time (ST), (2b) rest and personal time (RP), (2c) relocation time (RE), (2d) preparatory time $(\mathrm{PT})$, and $(2 \mathrm{e})$ interference time (IT) (Björheden \& Thompson 2000). All disturbance time caused by study related delays of the operation (e.g. by tree measuring or by interaction with time keepers) was removed from the data set during data analysis.

The felling and winching of each single tree constituted one monitoring and time recording cycle. Most of the trees were felled and winched in sequence. However, in some cases depending on the situation a few trees were consecutively felled and afterwards extracted. For the time study analysis, felling time, winching time and skidding time were individually recorded and standardized. The number of cycles monitored during the winching phase was lower than the number of recorded felling phases because of 39 low quality trees that were cut but not extracted. In addition, a lower number of cycles during log skidding to the landing occurred because, at times, multiple logs were forwarded per trip.

Statistical analyses were conducted using SPSS software version 22.0 (IBM Corp. Armonk/NY, USA). All data were checked for normality (non-parametric Whitney U Test; $p$ $<0.05$ ) before applying suitable testing methods for significance at the level $\alpha=0.05$. Net cycle times were numerically modeled through stepwise multiple linear regressions with variable transformation to model net-times predicted by independent variables using SPSS.

Table 2 Description of work elements of the productive work time

\begin{tabular}{ll}
\hline Work element & Description \\
\hline 1) Felling net time & $\begin{array}{l}\text { Search and change position; consideration and clearing of felling site; felling } \\
\text { tree and delimbing }\end{array}$ \\
2) Winching net time & Pulling cable to stem length log; choking; pulling log to road \\
3) Skidding net time & Bundling logs; skidding to landing; unloading; empty return \\
\hline
\end{tabular}


Felling net time was modeled in dependence of volume per tree, winching net time was modeled in dependence of the winching distances and skidding time was modeled in dependence of the skidding distance from felling site along the tractor road to landing. The harvesting method was considered in the models in form of a dummy variable $(\mathrm{CM}=0$ and $\mathrm{AM}=1)$. Total effective predicted time consumption was converted into net productivity and gross productivity (Mousavi 2012, Hoffmann et al. 2015).

\section{Cost estimation}

Machine cost were estimated according to the COST model for machine rate estimation (Ackerman et al. 2014). Fuel consumption was measured by starting work with a full tank and adding all necessary refills during and after work. Scheduled machine hours (SMH) per year were estimated considering available local capacities and interruptions because of high intensity rain patterns. The utilization rate with respect to productive machine hours per year $\left(\mathrm{PMH}_{0}\right.$ year $\left.^{-1}\right)$ was estimated based on the productivity observed during this case study. For scheduled shifts, 8 hours per day and
180 working days per year were considered (1440 SHM year ${ }^{-1}$ ), mainly because of limitations due to regional weather patterns with high intensity rainfalls resulting in annual precipitation ranging from $1100 \mathrm{~mm}$ to $2900 \mathrm{~mm}$ per year (Pandolfo et al. 2002).

The costs of insurance, repair, service and machine operating data were gathered from machine owners and from other sources (local market; forest service, Ackerman et al. 2014, ASABE 2011). Further details on cost calculation are given in table 3. Both harvesting methods used second hand purchased equipment, which is reflected in low investment costs for tractor and winch. This also resulted in a reduced amount of hours for the expected economic life.

\section{Results}

Within the monitored period of $65 \mathrm{SMH} 39 \mathrm{~h}$ of productive time $\left(\mathrm{PMH}_{0}\right)$ were recorded for the two harvesting methods in total, resulting in almost identical utilization rates of $60.8 \%$ and $60.9 \%$ for CM and AM, respectively. A total of 145, 99 and 65 repetitions were observed during the work elements of felling, winching

Table 3 Cost calculation for the equipment used for the conventional and alternative harvesting methods

\begin{tabular}{|c|c|c|c|c|}
\hline \multirow[b]{2}{*}{ Cost Item } & \multicolumn{2}{|c|}{ Conventional } & \multicolumn{2}{|l|}{ Alternative } \\
\hline & $\begin{array}{l}\text { Chainsaw } \\
\text { Stihl } 251\end{array}$ & $\begin{array}{l}\text { Tractor Valmet } \\
85 \text { with TMO } \\
\text { Winch }\end{array}$ & $\begin{array}{l}\text { Chainsaw } \\
\text { Stihl } 661\end{array}$ & $\begin{array}{l}\text { Tractor Valmet } 128 \\
\text { with TAJFUN Winch }\end{array}$ \\
\hline Investment $(€)$ & 735.00 & 13000.00 & 1200.00 & 19000.00 \\
\hline Interest rate $(\%)$ & 10 & 10 & 10 & 10 \\
\hline Service life $(\mathrm{PMH})$ & 1000 & 4500 & 1000 & 7000 \\
\hline Utilization (PMH year $\left.{ }^{-1}\right)$ & 211 & 621 & 184 & 693 \\
\hline Depreciation $\left(€\right.$ year $\left.^{-1}\right)$ & 155.58 & 1675.73 & 199.07 & 1964.95 \\
\hline Interest $\left(€\right.$ year $\left.^{-1}\right)$ & 44.82 & 776.29 & 75.95 & 115.75 \\
\hline Fuel cost $\left(€ \mathrm{PMH}^{-1}\right)$ & 0.32 & 3.69 & 0.41 & 4.23 \\
\hline Lubricants $\left(€ \mathrm{PMH}^{-1}\right)$ & 0.05 & 0.55 & 0.06 & 0.63 \\
\hline Maintenance cost $\left(€ \mathrm{PMH}^{-1}\right)$ & 0.59 & 3.70 & 0.96 & 4.77 \\
\hline Operator costs $\left(€ \mathrm{PMH}^{-1}\right)$ & 46.28 & 15.57 & 53.4 & 14.12 \\
\hline Productive costs $\left(€ \mathrm{~m}^{-3}\right)$ & 6.14 & 5.91 & 9.82 & 11.12 \\
\hline Total cost $\left(€ \mathrm{PMH}^{-1}\right)$ & 48.65 & 31.05 & 56.32 & 35.39 \\
\hline
\end{tabular}


and skidding to landing, respectively. The basic descriptive statistics of productive felling time, winching time, and skidding time are given in table 4 .

Although the characteristics of the felled trees at the test sites for the two harvesting methods were similar with respect to the independent variables mean $\mathrm{DBH}$, mean volume per tree, winching distance and skidding distance, statistically significant differences between the timing of the two analysed harvesting and extraction methods were evident in all of the examined work elements. Furthermore, felling time showed significant differences in the cycle elements "consideration and clearing of felling site" and "felling tree", while winching time showed the only difference for the cycle element "choking" as a consequence of applying the skidding cone. No significant differences were found in the other cycle el- ements of winching (pulling cable until stem length $\log$ and pulling log until road), which indicated that these cycle elements remained unaffected by the use of the skidding cone and of the snatch blocks.

When analyzing reasons for the relative low utilization rate of both methods it became obvious that interference time (IT) and service time (ST) determined most of the non-productive work time (Figure 3 ) of both methods. For CM IT accounted for $57 \%$ of delays while for AM ST accounted for $43 \%$ of delays. Reasons for IT during CM were logs getting stuck at other trees or rocks during winching. Although this situation was observed during $16 \%$ of the non-productive work time of CM, it was observed only during $2 \%$ of the non-productive work time of AM where the skidding cone was applied. On the other hand ST made up $22 \%$ of the delay time $(2.4 \mathrm{~h})$ of $\mathrm{CM}$ and it

Table 4 Descriptive statistics of the $\mathrm{PMH}_{0}$ (productive machine hours) work element and cycle element times with the number of observations valid and the standard deviations (SD)

\begin{tabular}{|c|c|c|c|c|c|c|c|c|c|}
\hline \multirow{2}{*}{$\begin{array}{l}\text { Work } \\
\text { element }\end{array}$} & \multirow{2}{*}{ Cycle element } & \multicolumn{4}{|c|}{ Conventional } & \multicolumn{4}{|c|}{ Alternative } \\
\hline & & $\mathrm{N}$ & Range & Mean & SD & $\mathrm{N}$ & Range & Mean & SD \\
\hline \multirow[t]{5}{*}{$\begin{array}{l}\text { Felling time } \\
(\mathrm{min})\end{array}$} & & 72 & $0.4-13.5$ & $4.3^{\mathrm{a}}$ & 2.1 & 73 & $0.5-17.0$ & $5.7^{\mathrm{b}}$ & 3.5 \\
\hline & $\begin{array}{l}\text { a) Search and change } \\
\text { position (min) }\end{array}$ & 72 & $0.0-4.7$ & $1.7^{\mathrm{a}}$ & 1.3 & 73 & $0.0-6.4$ & $1.5^{\mathrm{a}}$ & 1.5 \\
\hline & $\begin{array}{l}\text { b) Consideration and } \\
\text { clearing of felling site } \\
\text { (min) }\end{array}$ & 72 & $0.0-4.5$ & $0.5^{\mathrm{a}}$ & 0.7 & 73 & $0.0-4.8$ & $1.3^{\mathrm{b}}$ & 1.3 \\
\hline & c) Felling tree (min) & 72 & $0.1-2.7$ & $0.8^{\mathrm{a}}$ & 0.5 & 73 & $0.2-6.2$ & $1.4^{\mathrm{b}}$ & 1.2 \\
\hline & d) Delimbing (min) & 72 & $0.0-7.7$ & $1.2^{\mathrm{a}}$ & 1.5 & 73 & $0.0-7.0$ & $1.4^{\mathrm{a}}$ & 1.6 \\
\hline \multirow[t]{4}{*}{$\begin{array}{l}\text { Winching } \\
\text { time (min) }\end{array}$} & & 49 & $2.4-18.7$ & $7.3^{\mathrm{a}}$ & 3.9 & 50 & $2.7-32.2$ & $10.8^{\mathrm{b}}$ & 6.1 \\
\hline & $\begin{array}{l}\text { a) Pulling cable until } \\
\log (\min )\end{array}$ & 49 & $0.3-6.8$ & $2.3^{\mathrm{a}}$ & 1.5 & 50 & $0.5-16.0$ & $2.9^{\mathrm{a}}$ & 2.7 \\
\hline & b) Choking (min) & 49 & $0.2-3.1$ & $0.8^{\mathrm{a}}$ & 0.7 & 50 & $0.2-13.4$ & $2.5^{\mathrm{b}}$ & 2.6 \\
\hline & $\begin{array}{l}\text { c) Pulling log until } \\
\text { road (min) }\end{array}$ & 49 & $0.4-13.1$ & $4.2^{\mathrm{a}}$ & 3.1 & 50 & $0.7-12.6$ & $5.4^{\mathrm{a}}$ & 3.3 \\
\hline $\begin{array}{l}\text { Skidding } \\
\text { time (min) }\end{array}$ & & 33 & $2.9-19.6$ & $8.5^{\mathrm{a}}$ & 4.0 & 32 & $4.6-22.3$ & $11.9^{\mathrm{b}}$ & 5.1 \\
\hline \multicolumn{2}{|c|}{ Total net time $(\mathrm{min})$} & 75 & $0.4-40.8$ & $12.8^{\mathrm{a}}$ & 8.9 & 8.9 & $0.5-60.4$ & $17.3^{\mathrm{b}}$ & 13.2 \\
\hline \multirow{2}{*}{\multicolumn{2}{|c|}{$\begin{array}{l}\text { Winching distance }(\mathrm{m}) \\
\text { Skidding distance }(\mathrm{m})\end{array}$}} & 49 & $0.0-55.0$ & $25^{\mathrm{a}}$ & 15.0 & 57 & $0.0-55.0$ & $25.0^{\mathrm{a}}$ & 14.8 \\
\hline & & 34 & $200-470$ & $303^{\mathrm{a}}$ & 133.2 & 32 & $190-450$ & $255^{\mathrm{a}}$ & 114.4 \\
\hline
\end{tabular}

Note. Different lower case letters indicate significant differences $(p<0.05)$ in the mean values. 
took, as mentioned before, $43 \%$ of the delay time $(6.9 \mathrm{~h})$ of AM, mainly because of $4.0 \mathrm{~h}$ of repair time caused by unexpected mechanical problems with the winch or the tractor. With respect to IT, its biggest share of AM observed was the avoidable repositioning of and the tractor, accounting for $10 \%$ of the delay-time of both methods, mostly because of wrong estimation of skidding direction and wrong position of the tractor in the beginning of the cycle.

Stepwise linear regression analysis was conducted to estimate the time consumption as a function of the independent variables. The sta- tistical characteristics of the time consumption models are presented in table 5.

With respect to felling time $\left(T_{f e l}=2.30+\right.$ $3.35 \mathrm{x}_{\mathrm{vol}}+1.76 \mathrm{x}_{\mathrm{met}}$ ), the independent variables log volume and harvesting method showed a highly significant $(p<0.01)$ effect on the cycle time demand. Time demand for AM was on average $1.7 \mathrm{~min}$ higher compared to $\mathrm{CM}$. For the winching phase $\left(T_{w i n}=-0.99+0.29 \mathrm{x}_{\mathrm{wd}}+\right.$ $4.89 \mathrm{x}_{\mathrm{met}}$ ) the independent variables winching distance and harvesting method showed also a highly significant $(p<0.01)$ effect on cycle time. Skidding time to the landing $\left(T_{\text {Skid }}=0.77\right.$

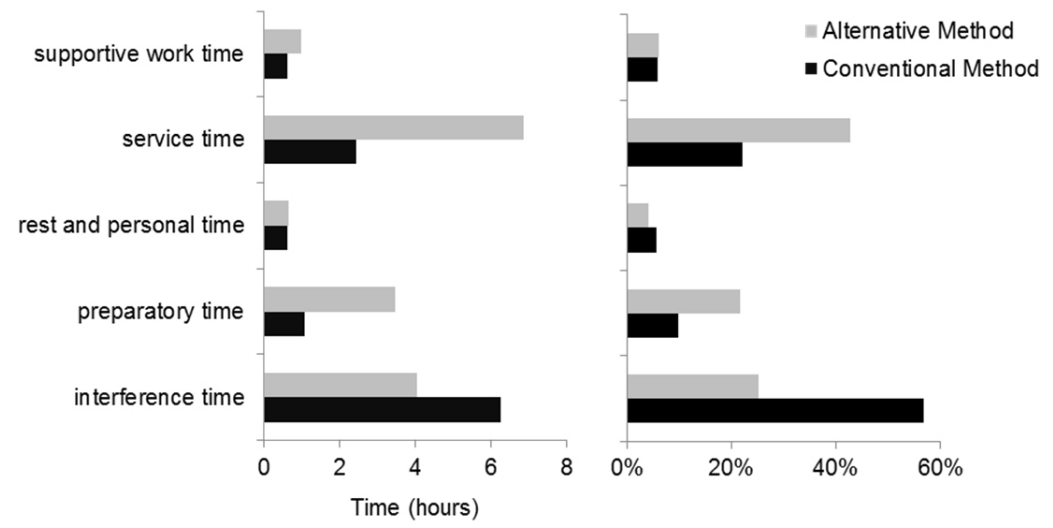

Figure 3 Proportion of the categorized non-productive time: SW (supportive work time), ST (service time), RP (rest and personal time), PT (preparatory time) and IT (interference time) of each method in absolute none work time demand (a) and percentage share among the total none work times (b).

Table 5 Summary of the linear regression models for the individual work elements

\begin{tabular}{|c|c|c|c|c|c|c|c|c|}
\hline \multirow{2}{*}{ Model } & \multirow{2}{*}{$\begin{array}{l}\text { Dependent } \\
\text { variable }\end{array}$} & \multirow{2}{*}{$R^{2}$} & \multicolumn{2}{|l|}{ F-test } & \multirow{2}{*}{$\begin{array}{l}\text { Constant/ } \\
\text { Coefficient }\end{array}$} & \multirow{2}{*}{$\begin{array}{l}\text { Esteemed } \\
\text { error }\end{array}$} & \multicolumn{2}{|c|}{$T$-test } \\
\hline & & & F-value & $p$ & & & $t$-value & $p$ \\
\hline \multirow{3}{*}{ Felling } & $T_{f e l}$ & 0.26 & 25.10 & $<0.001$ & +2.30 & 0.45 & 5.17 & $<0.001$ \\
\hline & & & & & $+3.35 \mathrm{x}_{\mathrm{vol}}$ & 5.35 & 6.27 & $<0.001$ \\
\hline & & & & & $+1.76 \mathrm{x}_{\mathrm{met}}$ & 4.45 & 3.96 & $<0.001$ \\
\hline \multirow{3}{*}{ Winching } & $T_{\text {win }}$ & 0.43 & 17.49 & $<0.001$ & -0.99 & 1.82 & -0.54 & 0.590 \\
\hline & & & & & $+0.29 \mathrm{x}_{\mathrm{wd}}$ & 0.06 & 4.72 & $<0.001$ \\
\hline & & & & & $+4.89 \mathrm{x}_{\mathrm{met}}$ & 1.33 & 3.68 & $<0.001$ \\
\hline \multirow{3}{*}{$\begin{array}{l}\text { Skidding to } \\
\text { Landing }\end{array}$} & $T_{\text {skid }}$ & 0.55 & 37.74 & $<0.001$ & +0.77 & 1.16 & 0.66 & 0.510 \\
\hline & & & & & $+0.02 \mathrm{x}_{\mathrm{sd}}$ & 0.00 & 7.66 & $<0.001$ \\
\hline & & & & & $+4.63 \mathrm{x}_{\mathrm{met}}$ & 0.83 & 5.57 & $<0.001$ \\
\hline
\end{tabular}

Note. Abbreviations: $T_{\text {fel }}$ - time consumption during the felling, $T_{\text {win }}$ - time consumption during the winching, $T_{\text {skid }}$ - time consumption during skidding to landing, $\mathrm{x}_{\mathrm{vol}}$ - tree volume, $\mathrm{x}_{\mathrm{met}}$ - method, $\mathrm{x}_{\mathrm{wd}}$ - winching distance, $\mathrm{x}_{\mathrm{sd}}$ - skidding distance to landing. 
$+0.02 \mathrm{x}_{\mathrm{sd}}+4.63 \mathrm{x}_{\mathrm{met}}$ ) was depending (high significance $p<0.01$ ) on skidding distance and harvesting method.

Based on time consumption models and mean log volume $\left(0.636 \mathrm{~m}^{3} \mathrm{PMH}_{0}^{-1}\right)$, felling productivity amounted to $8.6 \mathrm{~m}^{3} \mathrm{PMH}_{0}^{-1}$ for $\mathrm{CM}$ and $6.2 \mathrm{~m}^{3} \mathrm{PMH}_{0}^{-1}$ for AM. Winching productivity, based on mean winching distance $(25 \mathrm{~m})$, was estimated $6.2 \mathrm{~m}^{3} \mathrm{PMH}_{0}^{-1}$ for $\mathrm{CM}$ and $3.5 \mathrm{~m}^{3} \mathrm{PMH}_{0}^{-1}$ for AM. Furthermore, skidding productivity, based on mean skidding distance $(280 \mathrm{~m})$, was found to be $4.9 \mathrm{~m}^{3} \mathrm{PMH}_{0}^{-1}$ for $\mathrm{CM}$ and $3.1 \mathrm{~m}^{3} \mathrm{PMH}^{-1}$ for AM. Since hourly productivity of skidding was the lowest among the three work elements (felling, winching, skidding) in both harvesting methods, it was identified as the bottleneck of the operations. Hence, to quantify overall productivity on hourly level for the respective harvesting method, all three work stages were standardized to time demand of the skidding stage, generating total outputs of $4.9 \mathrm{~m}^{3} \mathrm{PMH}_{0}^{-}$ ${ }^{1}$ for $\mathrm{CM}$ and $3.1 \mathrm{~m}^{3} \mathrm{PMH}_{0}^{-1}$ for $\mathrm{AM}$ resulting in gross-productivities of $3.0 \mathrm{~m}^{3} \mathrm{SMH}^{-1}$ for $\mathrm{CM}$ and $1.9 \mathrm{~m}^{3} \mathrm{SMH}^{-1}$ for AM.

With the observed utilization rate $(\mathrm{CM}$ $60.8 \%$ and AM $60.9 \%$ ) the estimated $\mathrm{PMH}_{0}$ per year were $826 \mathrm{~h}$ and $877 \mathrm{~h}$ for CM and AM, respectively. Moreover, based on the time models for the observed operations under given stand conditions, CM took $0.48 \mathrm{~h}$ for producing one cubic meter timber and skidding it to the landing with $24 \%$ of the time demand for felling, $34 \%$ for winching and $42 \%$ for skidding to landing. AM required $0.70 \mathrm{~h}$ to produce and transport one cubic meter of timber to the landing with a share of $21 \%, 37 \%$ and $42 \%$ of the time demand for felling, winching and skidding to landing, respectively.

Based on this, for CM total annual operating hours of chainsaw and tractor winch amounted to $211 \mathrm{~h}$ and $621 \mathrm{~h}$, respectively. Application of AM resulted $184 \mathrm{~h}_{\text {year-1 }}{ }^{-1}$ and $693 \mathrm{~h}_{\text {year }}{ }^{-1}$ annual operating hours for the chainsaw and the tractor winch, respectively. Assuming similar productivities as observed, relatively low annual production outputs of $4000 \mathrm{~m}^{3}$ for CM and $2700 \mathrm{~m}^{3}$ for AM are expected. System costs for the described set ups of CM and AM were estimated to be $79.29 € \mathrm{PMH}^{-1}$ for $\mathrm{CM}$ and $91.70 € \mathrm{PMH}^{-1}$ for $\mathrm{AM}$. This resulted in actual harvesting and extraction net-cost estimates of $12.05 € \mathrm{~m}^{-3}$ for $\mathrm{CM}$ and $20.94 € \mathrm{~m}^{-3}$ for AM.

\section{Discussion}

This case study had the objective to estimate production rates and costs of two harvesting systems in a secondary forest, as well as to conclude on future opportunities for the sustainable timber harvesting operations. Special care was taken regarding terrain conditions and the comparability of the selected two stands, in order to relate observed operational difference in the two stands purely to the harvesting methods. Thus, it was confirmed, as in earlier studies, that the most significant factors affecting productivity in both methods were tree dimensions (volume) (Jourgholami et al. 2013, Koutsianitis \& Tsioras 2016) and extraction distances (winching distance and skidding distance to landing) (Mousavi 2012, Hoffmann et al. 2015, Hoffmann et al. 2016).

Comparing the two methods, $\mathrm{CM}$ required less time per work element, with a corresponding higher productivity at lower costs then AM. This occurred mostly because for AM both operators, the professional chainsaw operator and the tractor operator, were not familiar with characteristics of the Atlantic Forest and related harvesting and extraction conditions, such as low tree dimensions and very dense forest stands. The chainsaw operator knew the context of the Amazon high forest which is characterized by felling trees with DBH exceeding $50 \mathrm{~cm}$ (Bauch et al. 2007) while the mean harvested DBH of our test plots was about $25 \mathrm{~cm}$. The before mentioned lower stem volume in dense stands also resulted in prolonged felling time due to lags by hindering the felling process since trees were rather leaning onto neighboring trees instead of freely falling 
down. The tractor operator working in AM had never worked in a natural forest before. The winding forest roads of varying widths and gradients together with uneven landing areas were most likely some of the reasons for the prolonged skidding times of AM. Lopes \& Pagnussat (2017) pointed out that a lower performance rate was expected in the execution of the operation during the training period, as the operators were adapting to new environmental conditions and techniques required for quick decision and uninterrupted operation. Therefore the lacking availability of a professional operator (chainsaw and tractor) familiar with specifcs of timber harvesting operations in the Atlantic Forest was a major limitation of this factorial experiment. An extra period of training of AM chainsaw and tractor operators before the beginning of the case study to get more familiar with local terrain and stand conditions would have been needed and could have led to different results. However, this could not be realized due to time and resource constrains within the presented study and has to be considered when interpreting the results.

In addition, the application of skidding cone also showed a significant extra time effort during the "chocking" in AM, however it reduced IT (interference time) by reducing delay time of stuck logs from $16 \%$ in CM to only $2 \%$ in AM. Additionally as proofed by Acar (2016) the skidding cone can reduce the risk of hitting remaining trees, causing future log devaluation, and generally also reduces ground disturbances caused by the extraction. Moreover, the addition of the snatch block did not significantly increase the time demand during winching and, consequently, did not affect productivity. This is in line with the observations of Piccho et al. (2012), who did not identify a significant work time demand increase for the use of snatch blocks in Italian operations.

More remarkable delays for AM were observed by ST (service time) with an unexpected high demand of repair time $(4.0 \mathrm{~h})$ for AM. An extra period of preparatory time ahead of the case study could have reduced such inter- ferences by improved machine handling (e.g. training of maintenance routines). If we would disregard this extra needed time for the repair time, the utilization rate for AM would increase to $68 \%$, which would be in accordance with Holzleitner et al. (2011) who described utilization rates of forest machines ranging from $62 \%$ to $70 \%$. However, considering this increased utilization rate, the operational costs for AM would amounted to $19.25 € \mathrm{~m}^{-3}$, which is still significantly higher compared to $\mathrm{CM}$ $\left(12.05 € \mathrm{~m}^{-3}\right)$.

Although AM showed lower productivity and higher costs, it enabled important improvements of the operation in terms of occupational health and safety by reduced impact and risky felling techniques (e.g. directional felling technique). It also allowed for enhanced safety features of the winch such as cable guards. Additionally, in some cases, CM in combination with low to none training of the chainsaw operator in appropriate felling techniques with overconfidence ended up in dangerous situations, as witnessed by the authors.

\section{Conclusions}

While the presented results add new information on productivities and influencing factors of the two analysed harvesting and extraction methods only very limited conclusions can be drawn on their environmental impacts on the remaining stand. Therefore, for a comprehensive evaluation of the two harvesting methods with recommendation on best practice operations for the Atlantic Forest management, a more refined study covering environmental impacts and post-harvest forest recovery is required. CM showed higher productivity at lower costs in a direct comparison with a proposed improved AM, however AM represented an important improvement for the operation in terms of occupational health and safety. Therefore, for the sustainable management of the Atlantic Forest, a suitable harvesting system should integrate local experiences of $\mathrm{CM}$ 
and proposed technical improvements of AM.

\section{Acknowledgements}

The authors would like to express their sincere thanks for the financial support from Barbara und Elisabeth Grammel Studienstiftung; in particular to Eva Mayr-Stihl Stiftung; Georg Ludwig-Hartig Stiftung; Wissenschaftliche Gesellschaft Freiburg. In addition, the authors very much appreciated the support from $\mathrm{Mr}$. Clemente Bizewisky and Mr. Cristiano Bizewisky; TAJFUN Brazil; Tropical Forest Institute (IFT); Mr. Sarunas Jomatas; Mr. Heitor Felipe Uller; Mrs. Aline Klitzke; Mr. Gabriel Bollmann, Mrs. Erica Pereira and Mr. Gefferson Elias Piazza.

\section{References}

Acar H.H., 2016. Log pulling sliding head to be used during cable skidding by drummed tractor. In: Gendek A., Moskalik T. (eds.), Proceedings of the $49^{\circ}$ FORMEC symposium, 4-7 September 2016, Warsaw Poland. Warsaw University of Life Sciences, Warsaw, pp. 23-25.

Ackerman P., Belbo H., Eliasson L., Jong A., Lazdins A., Lyons J., 2014. The COST model for calculation of forest operations costs. International Journal of Forest Engineering 25(1): 75-81. DOI: 10.1080/14942119.2014.903711

Alarcon G.G., Caporal D.S., Beltrame A.V., Karam K.F., 2011. Transformação da paisagem e uso dos recursos florestais na agricultura familiar: um estudo de caso em área de Mata Atlântica [Landscape change and the use of forest resources in family agriculture: a case study in the atlantic forest region]. Ciência Florestal 21: 369380. DOI: $10.5902 / 198050983242$

Alarcon G. G., Ayanu, Y., Fantini A. C., Farley J., Filho A. S., Koellner T., 2015. Weakening the Brazilian legislation for forest conservation has severe impacts for ecosystem services in the Atlantic Southern Forest. Land Use Policy 47: 1-11. DOI: 10.1016/j.landusepol.2015.03.011

ASABE, American Society of Agricultural and Biological Engineers, 2011. Agricultural machinery management data ASAE D4977. ASABE Standards, St. Joseph: 1-8.

Akay, E. A., Yilmaz, M., Tonguc, F., 2006. Impact of mechanized harvesting machines on forest ecosystem: Residual stand damage. Journal of Applied Sciences
6(11): 2414-2419. DOI: 10.3923/jas.2006.2414.2419

Bauch, S., Amacher, G., Merry, F., 2007. Costs of harvesting, transportation and milling in the Brazilian Amazon: Estimation and policy implications. Forest Policy and Economics 9(8): 903-915. DOI: 10.1016/j. forpol.2006.07.004

Björheden R.; Thompson M. A., 2000. An international nomenclature for forest work study. In: Field D.B. (ed.), Proceeings of IUFRO 1995: 20th World Congress, 6-12 August 1995, Tampere Finland. University of Maine, Orono, pp. 190-215.

IBGE, 2012. Manual Técnico da Vegetação Brasileira. Série Manuais Técnicos em Geociências 1, $2^{a}$ edição revista e ampliada [Technical manual of Brazilian vegetation in technical manuals series of geosciences.]. IBGE, Rio de Janeiro, $271 \mathrm{p}$.

Klein R.M., 1978. Mapa fitogeográfico do estado de Santa Catarina [Phytogeographic map of Santa Catarina state]. Herbário Barbosa Rodrigues 5: 1-24.

Koutsianitis D., Tsioras P., 2016. Time consumption and production costs of two small scale wood harvesting systems in northern Greece. Small Scale Forestry 16: 19-35. DOI: 10.1007/s11842-016-9340-3

Jourgholami M., 2012. Small scale timber harvesting: mule Logging in Hycranian forest. Small Scale Forestry 11: 255-262. DOI: 10.1007/s11842-011-9174-y

Fantini A.C., Siminski A., 2016. Manejo de florestas secundárias da Mata Atlântica para produção de madeira: possível e desejável [Management of secondary forests of the Brazilian Atlantic Forest for timber production: possible and desirable]. Revista Brasileira de Pós-Graduação 13(32): 673-698. DOI: 10.21713/23582332.2016.v13.1013

Hoffmann S., Jaeger D., Schoenherr S., Lingenfelder M., Sun D., Zeng J., 2016. The effect of forest management systems on productivity and costs of cable yarding operations in the southern China. Forestry Letters 109: 11-24.

Hoffmann S., Jaeger D., Schoenherr S., Talbot B., 2015. Challenges in mechanization efforts of small diameter eucalyptus harvesting operations with a low capacity running skyline yarder in southern china. Forests 6(9): 2959-2981. DOI: 10.3390/f6092959

Holzleitner, F., Stampfer, K., Visser, R., 2011. Utilization rates and cost factors in timber harvesting based on long-term machine data. Croatian Journal of Forest Engineering 32(2): 501-508.

Lopes, E. S., Pagnussat, M. B., 2017. Effect of the behavioral profile on operator performance in timber harvesting. International Journal of Forest Engineering 62: 1-6. DOI: $10.1080 / 14942119.2017 .1328847$

Magagnotti N., Spinelli R., 2012. Good practice guidelines for biomass production studies. CNR Ivalsa, Sesto Fiorentino, $54 \mathrm{p}$.

Metzger J.P., 2009. Conservation issues in the Brazilian Atlantic Forest. Biological Conservation 142(6): 11381140. DOI: 10.1016/j.biocon.2008.10.012 
Mousavi R., 2012. Time consumption productivity and cost analysis of skidding in the Hyrcanian forest in Iran. Journal of Forestry Research 23: 691-697. DOI: 10.1007/s11676-012-0265-1

Pandolfo, C., Braga H. J., Silva V. P., Massignan A. M., Pereira E.S., Thomé V.M.R., 2002. Atlas climatológico digital do Estado de Santa Catarina [Climatological atlas of Santa Catarina state]. EPAGRI, Florianópolis.

Picchio, R., Magagnotti, N., Sirna, A., Spinelli, R., 2012. Improved winching technique to reduce logging damage. Ecological Engineering 47: 83-86. DOI: 10.1016/j. ecoleng.2012.06.037

Ribeiro M. C., Metzger J. P., Martensen A. C., Ponzoni F. J., Hirota M. M., 2009. The Brazilian Atlantic Forest: How much is left and how is the remaining forest distributed? Implications for conservation. Biological Conservation 142(6): 1141-1153. DOI: 10.1016/j.biocon.2009.02.021

Sabogal C., Silva J. N. M., Zweede, J., Pereira Júnior R., Barreto P., Guerreiro C. A., 2000. Diretrizes técnicas para a exploração de impacto reduzido em operações florestais de terra firme na Amazônia Brasileira [Technical Guidelines for the reduced impact logging in the Brazilian Amazon Forest.]. Embrapa Amazônia Oriental, Belém, 52 p.

Silva W. G., Metzger J. P., Simões S., Simonetti C., 2007. Relief influence on the spatial distribution of the Atlantic Forest cover at the Ibiúna Plateau. Brazilian Journal of Biology 67(3): 403-411. DOI: 10.1590/S151969842007000300004 